J. Appl. Glycosci., 53, 115-122 (2006)

(C) 2006 The Japanese Society of Applied Glycoscience

Proceedings of the Symposium on Amylases and Related Enzymes, 2005

\title{
Fungal Exo-acting Enzymes with Novel Catalytic Properties
}

\author{
(Received December 30, 2005) \\ Tatsuji Sakamoto ${ }^{1, *}$ \\ ${ }^{1}$ Division of Applied Life Sciences, Graduate School of Life and Environmental Sciences, Osaka Prefecture University \\ (1-1, Gakuen-cho, Osaka 599-8531, Japan)
}

\begin{abstract}
This article deals with characterizations of two Aspergillus niger exo-polygalacturonases (exo-PGs; EC 3.2.1.67) and a Penicillium chrysogenum exo-arabinanase (no EC number). Two exo-PGs, termed exo-PG1 and -PG2, purified from a commercial A. niger enzyme preparation (Pectinex AR) had molar masses of 82 and $56 \mathrm{kDa}$, respectively. Exo-PG1 was stable over wider pH and temperature ranges than exo-PG2. Exo-PG1 had a broad specificity towards oligogalacturonates with different DPs, while digalacturonate was the most favorable substrate for exo-PG2. Both enzymes degraded xylogalacturonan from pea hull in an exo manner to produce galacturonic acid (GalA) and Xyl-GalA disaccharide, as identified by electrospray ion trap mass spectrometry (ESI-ITMS). Moreover, exo-PGs split acetylated homogalacturonan in an exo manner, producing GalA and acetylated GalA, as shown by ESI-ITMS. An exo-arabinanase, termed Abnx, was purified from a culture filtrate of $P$. chrysogenum 31B. The enzyme released only arabinobiose from the non-reducing terminus of $\alpha-1,5-\mathrm{L}$-arabinan and showed no activity towards $p$-nitrophenyl $\alpha$-L-arabinofuranoside or $\alpha-1,5-\mathrm{L}-$ arabinofuranobiose. The nucleotide sequence of the $a b n x$ cDNA gene, which encodes Abnx, was determined. Abnx was found to be structurally distinct from known arabinan-degrading enzymes based on its amino acid sequence and a hydrophobic cluster analysis (HCA). The abnx cDNA gene product expressed in Escherichia coli catalyzed the release of arabinobiose from $\alpha-1,5-\mathrm{L}$-arabinan. The activity of the recombinant Abnx towards a series of arabino-oligosaccharides, as expressed by $k_{c a t} / K_{m}$ value, was greatest with arabinohexaose. The recombinant enzyme was found to possess trans-arabinobiosylation activity on various acceptors, such as aliphatic alcohols, sugars and sugar alcohols. The transfer product of glycerol was identified as $O$ - $\alpha-\mathrm{L}-$ arabinosyl- $(1 \rightarrow 5)-O$ - $\alpha$-L-arabinosyl- $(1 \rightarrow 1)$-glycerol on the basis of the spectral data, fast atom bombardmentmass (FAB-MS) and ${ }^{1} \mathrm{H}$ - and ${ }^{13} \mathrm{C}$-NMR. Unlike endo-arabinanases, Abnx catalyzed the hydrolysis of linear arabinan without inverting the anomeric configuration.
\end{abstract}

Key words: exo-polygalacturonase, xylogalacturonan, acetylated homogalacturonan, exo-arabinanase, arabinobiose

Pectins are acidic polysaccharides of high molar mass and one of the main components of the primary cell walls of dicotyledons. Pectins consist of homogalacturonic or "smooth" regions, and rhamnogalacturonic or "hairy" regions carrying neutral sugar side-chains. GalA residues may be substituted by different compounds such as methanol, acetic acid and xylose, in the "smooth" as well as in the "hairy" region. The carboxyl groups of pectin are partially esterified with methanol, and the hydroxyl groups at position 2 or/and 3 of GalA residues are sometimes acetylated. Xylogalacturonan, an $\alpha-1,4-\mathrm{D}$-galacturonan to which D-xylopyranose units are attached at position $\mathrm{O}-3$ in the $\beta$-configuration as side chains, can be found in cell walls such as japanese radish, ${ }^{1)}$ carrot, ${ }^{2)}$ soy ${ }^{3)}$ and apple. ${ }^{4}$ In pea hull xylogalacturonan, the degree of substitution of GalA by xylose residues is $72 \%$. GalA

\footnotetext{
* Tel. +81-72-254-9456, Fax. +81-72-254-9921, E-mail : sakamoto@biochem.osakafu-u.ac.jp.

Abbreviations: AHG, acetylated homogalacturonan; DAc, degree of acetylation; DM, degree of methylation; ESI-ITMS, electrospray ion trap mass spectrometry; Exo-PG, exo-polygalacturonase; FAB-MS, Fast atom bombardment-mass spectrometry; GalA, galacturonic acid; HCA, hydrophobic cluster analysis; HG, homogalacturonan; HPAEC, high-performance anion-exchange chromatography; MBP, maltose binding protein; $\mathrm{PAD}$, pulsed amperometric detection.
}

residues carry mainly single terminal xylose residues attached on O-3 and a few short side chains of xylosyl residues linked on O-2 or sometimes on O-3. ${ }^{5)}$ In contrast, arabinans and arabinogalactans are most frequently found in hairy regions of pectins. Sugar beet and apple pectins are characterized as containing high amounts of branched L-arabinan, a highly branched $\alpha-1,5$-L-arabinan possessing 1,2 or $1,3-\alpha$-linked L-arabinofuranosyl residues as sidechains. Arabinogalactan, which has a linear chain of $\beta$ 1,4-D-galactan to which $\alpha$-1,5-L-linked arabinofuranooligosaccharides are bound in side-chains, is rich in soybean pectin. Extensive degradation of pectic polysaccharides is important in the processing of plant materials such as the clarification of fruit juices. ${ }^{\text {) }}$ Enzymatic degradation of pectic polysaccharides is also efficient for their structural analysis since enzymes have strict substrate specificities. Exo-acting enzymes are especially useful in this field because they can split polysaccharides from the terminus sequentially.

This paper deals with characterizations of exo-acting enzymes with novel catalytic properties, which include two A. niger exo-PGs and a $P$. chrysogenum exo-arabinanase. 
Two exo-PGs from A. niger able to degrade xylogalacturonan and acetylated homogalacturonan. ${ }^{7}$

Two exo-PGs were isolated from the commercial $A$. $n i$ ger enzyme preparation Pectinex AR (Novozymes, France). SDS-PAGE analysis of the purified enzymes showed a single protein band at a molar mass of 82 and $56 \mathrm{kDa}$ for exo-PG1 and exo-PG2, respectively. Exo-PG1 was stable over a wider $\mathrm{pH}$ range and over a wider temperature range than exo-PG2. Addition of $0.01 \mathrm{mM} \mathrm{HgCl}_{2}$ increased exo-PG2 activity by 3.4 times and had no effect on exo-PG1 activity. Exo-PG2 was deduced to be similar to the A. niger exo-PGs reported by Mill ${ }^{8)}$ and Hara et al.$^{9)}$ which were also stimulated by $\mathrm{Hg}^{2+}$. The A. tubingensis exo-PG is an enzyme with a molar mass of 78,000, broad specificity towards oligogalacturonates (mentioned below), and non-sensitive to $\mathrm{Hg}^{2+}$. ${ }^{10)}$ Taking into account these properties, exo-PG1 seems to be similar to this enzyme.

Table 1 shows the specificities of the purified exo-PGs on galacturonates with different DPs at a $0.1 \mathrm{mM}$ concentration. Digalacturonate was the favorite substrate for the action of exo-PG2, which seemed to prefer oligogalacturonates to homogalacturonan $(\mathrm{HG})$. On the other hand, exo-PG1 had a broad specificity towards galacturonates with different DPs compared to exo-PG2 and was also active on the polymer. Degradation of various plant cell wall polysaccharides by exo-PGs was also investigated (Table 2). The enzymes exhibited the highest activity towards HG. Sugar beet pectin was the poorest substrate for both enzymes. The activities on de-esterified sugar beet pectin were higher than those on sugar beet pectin in both enzymes. These substrates had similar quantities of "hairy" regions but different degree of methylation (DM) and degree of acetylation (DAc). The differences of sub-

Table 1. Enzyme activity of the exo-PGs towards galacturonates with different DPs.

\begin{tabular}{lcc}
\hline & \multicolumn{2}{c}{ Relative activity } \\
\cline { 2 - 3 } Substrate & Exo-PG1 & Exo-PG2 \\
\hline DP 2 & 100 & 100 \\
DP 3 & 86 & 40 \\
DP 4 & 72 & 16 \\
DP 5 & 63 & 13 \\
DP 149 & 42 & 5 \\
\hline
\end{tabular}

The enzyme was incubated with $100 \mu \mathrm{L}$ of $0.1 \mathrm{~mm}$ the substrate in $50 \mathrm{~mm}$ sodium acetate- $\mathrm{HCl}$ buffer $\left(\mathrm{pH} \mathrm{3.6)}\right.$ at $40^{\circ} \mathrm{C}$ for $10 \mathrm{~min}$. Concentration of GalA released was determined by HPAEC. strate specificity seemed to be due to DM or DAc. Highly methylated pectin (Grinsted ${ }^{\mathrm{TM}}$ Pectin URS 1200; E81) was also considerably resistant to the enzymes, indicating that methyl ester groups interfered with the enzyme activities. An A. niger exo-PG has been reported to be able to release free GalA from the nonreducing terminus only when the following GalA is not methyl-esterified. ${ }^{11)}$ Acetylated homogalacturonan (AHG) could be degraded to some extent by the enzymes although most GalA residues in this substrate are esterified with acetate (45\% of DAc) or methanol (24\% of DM). This result suggests that the exoPGs released acetylated GalA. Enzyme activities of the exo-PGs on xylogalacturonan were low. High-performance anion-exchange chromatography (HPAEC) profiles of the reaction products of the substrate with each enzyme revealed that both enzymes released GalA as the main product accompanied with an unknown compound. Figure 1 shows an example for exo-PG2.

To study the mode of action of exo-PGs on xylogalacturonan, the unknown compound released from the substrate by exo-PG2 was isolated on a CarboPac PA-1 column (Dionex) and analyzed by both positive and negative ESI-ITMS and by acid hydrolysis. In positive ESI-ITMS, two major ions with molar masses of 349 and 675 were observed, which were assigned to be the sodiated molecules $[\mathrm{M}+\mathrm{Na}]^{+}$and $[2 \mathrm{M}+\mathrm{Na}]^{+}$, respectively. Negative ESI-ITMS gave an intensive peak at 325 corresponding to

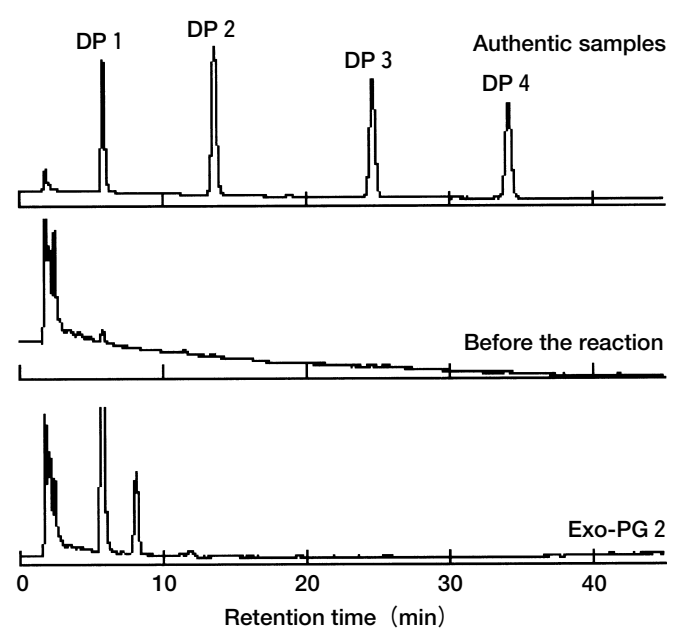

Fig. 1. HPAEC analysis of the enzymatic products of pea hull xylogalacturonan obtained with exo-PG2.

Authentic samples DP 1 to DP 4 represent GalA to tetragalacturonate, respectively.

Table 2. Sugar compositions and enzyme activity of exo-PGs on various substrates.

\begin{tabular}{|c|c|c|c|c|c|c|c|c|c|}
\hline \multirow{2}{*}{ Substrate } & \multicolumn{5}{|c|}{ Sugar composition (mg/g) } & \multirow{2}{*}{$\begin{array}{l}\text { DAc } \\
(\%)\end{array}$} & \multirow{2}{*}{$\begin{array}{l}\mathrm{DM} \\
(\%)\end{array}$} & \multicolumn{2}{|c|}{$\begin{array}{l}\text { Amount of GalA released } \\
\qquad(\mu \mathrm{g} / \mathrm{mL})\end{array}$} \\
\hline & Rha & Ara & Xyl & Gal & AUA & & & Exo-PG1 & Exo-PG2 \\
\hline SBP & 30 & 213 & 3 & 53 & 414 & 49 & 51 & 1 & 1 \\
\hline DE-SBP & 32 & 202 & 3 & 54 & 461 & 26 & 15 & 38 & 65 \\
\hline $\mathrm{HG}$ & 2 & 0 & 0 & 0 & 804 & $<1$ & $<3$ & 106 & 186 \\
\hline AHG & 35 & 53 & 2 & 53 & 586 & 45 & 24 & 23 & 38 \\
\hline E81 & 14 & 3 & - & 44 & 877 & - & 81 & 8 & 19 \\
\hline XG & - & - & 282 & - & 413 & 3 & 0 & 14 & 8 \\
\hline
\end{tabular}

SBP, sugar beet pectin; DE-SBP, de-esterified sugar beet pectin; HG, homogalacturonan; AHG, acetylated homogalacturonan; E81, highly methylated pectin; XG, xylogalacturonan; AUA, anhydro uronic acid; DAc (\%), degree of acetylation; DM (\%), degree of methylation. 
the deprotonated $[\mathrm{M}-\mathrm{H}]^{-}$. These results indicated that the molar mass of the compound was 326. Moreover, acid hydrolysis of the compound and its alditol acetate derivative gave a peak corresponding to xylose in gas liquid chromatography. It could then be concluded that the unknown product was the disaccharide (Xyl-GalA) composed of xylose $\left(M_{\mathrm{r}}=150\right)$ and GalA $\left(M_{\mathrm{r}}=194\right)$. Furthermore, positive and negative ESI-MS/MS gave intensive daughter ions at $217(194+23)$ and $175(194-18-1)$, respectively, when molecular ions of Xyl-GalA were selected to be trapped. Cleavages of glycosidic linkages occur preferentially at the nonreducing and reducing side of the glycosidic oxygen in positive and negative ESI-MS/ MS, respectively. ${ }^{12,13)}$ Therefore, it can be concluded that the compound was Xyl $\rightarrow$ GalA. Considering the structure of xylogalacturonan, it is likely that this disaccharide is $\mathrm{Xyl} \rightarrow 3 \mathrm{GalA}$. These results demonstrated that both enzymes degraded xylogalacturonan in an exo manner, producing GalA and Xyl-GalA. The progression of products released by exo-PG2 on xylogalacturonan is shown in Fig. 2. During the early stage of the reaction, the enzyme released GalA more easily than the disaccharide. When the incubation was prolonged, the enzyme gradually produced the disaccharide. This data suggested that the enzyme had higher affinity for the non-substituted GalA residues than for those substituted with xylose. Our previous results about the fine structure of xylogalacturonan demonstrated that $28 \%, 53 \%$ and $19 \%$ of the total GalA residues were free, substituted with a single xylose, and with dixylosides, respectively. ${ }^{5}$ When the percentages and sugar content of the substrate were taken into account (Table 2), concentrations of GalA, Xyl-GalA and Xyl-XylGalA units in xylogalacturonan of the reaction mixture were calculated to be 96,319 and $163 \mu \mathrm{g} / \mathrm{mL}$, respectively. Exo-PG2 released $40.1 \mu \mathrm{g} / \mathrm{mL}$ of $\mathrm{GalA}$ and 60.2 $\mu \mathrm{g} / \mathrm{mL}$ of Xyl-GalA after $48 \mathrm{~h}$ of reaction, demonstrating that $42 \%$ and $19 \%$ of free GalA residues and Xyl-GalA units were released and that $22 \%$ of total glycosidic link-

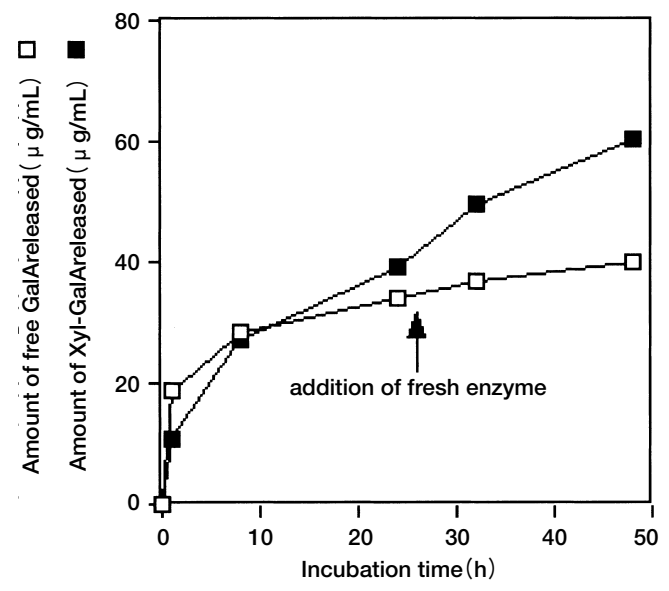

Fig. 2. Progression of products released by exo-PG2 on pea hull xylogalacturonan.

A reaction mixture containing $0.3 \mathrm{~mL}$ of $0.1 \%$ xylogalacturonan in $50 \mathrm{~mm}$ sodium acetate- $\mathrm{HCl}$ buffer $(\mathrm{pH} \mathrm{3.6)}$ and $60 \mu \mathrm{L}$ of the enzyme $(50 \mathrm{mU})$ was incubated at $40^{\circ} \mathrm{C}$ at times shown. The fresh enzyme $(25 \mathrm{mU})$ was added to the mixture at $24 \mathrm{~h}$ after the reaction started. The products released into the mixture were quantified by HPAEC. ages between GalA were cleaved. The high percentage of free GalA released may indicate that xylogalacturonan had HG regions without xylose substitution. During degradation of xylogalacturonan, GalA and Xyl-GalA were predominantly formed and little quantities of two other compounds, which have not been identified, were also produced. Even though $19 \%$ of the total GalA is substituted by dixylosides, there was not an intensive peak corresponding to Xyl-Xyl-GalA. This suggested that substitution with dixylosides interfered with the activity of exoPG2.

As mentioned above, exo-PGs seemed to degrade AHG extracted from sugar beet pectin, which is characterized by a high DAc at O-2 and/or O-3 of the GalA in the backbone. Taking into account the ability of exo-PGs to split xylogalacturonan and its chemical structure, our interest was focused on the degradation of AHG by these enzymes. To confirm the release of acetylated GalA from AHG with exo-PGs, we tried to separate acetylated and free GalA by reverse phase chromatography. Reaction products of AHG with two exo-PGs were analyzed using a Superspher column (Merck), which gave an unknown compound in addition to GalA (data not shown). The compound was then purified with the same column and treated with $0.1 \mathrm{M}$ sodium hydroxide for $2 \mathrm{~h}$ at room temperature. The unknown compound disappeared and GalA and acetic acid appeared, which strongly suggested that GalA was esterified with acetic acid. Then, the unknown product was analyzed by ESI-ITMS, which gave a molar mass of 259 in positive ESI-ITMS and 235 in negative ESI-ITMS, respectively. From these results, it can be concluded that the unknown compound was acetylated GalA.

In conclusion, both exo-PGs isolated here degraded pea hull xylogalacturonan in an exo manner to produce GalA and Xyl-GalA, which was identified by analyses of HPAEC, ESI-ITMS, and acid hydrolysis. So far, exo-PGs produced by both $A$. aculeatus $^{3)}$ and $A$. tubingensis ${ }^{14)}$ have been reported to be able to split the saponified soy and apple xylogalacturonan, respectively. Moreover, one enzyme termed endo-xylogalacturonan hydrolase found in $A$. tubingensis ${ }^{15}{ }^{1}$ was able to cleave a xylose-substituted GalA backbone but not HG. These enzymes would be useful for structural analysis of plant cell walls as well as the processing of xylogalacturonan-rich materials. Degradation activity on AHG was also a new feature of $A$. niger exo-PGs. GalA and acetylated GalA as the reaction products could be separated by using a C18 column. To our knowledge, it is the first report on the degradation of AHG by an exo-PG. Exo-PGs could be applied for degradation of sugar beet pectin, which has a high DAc, in combination with other pectolytic enzymes and also for analysis of acetylation pattern in HG.

\section{Exo-arabinanase of $P$. chrysogenum able to release arabinobiose from $\alpha-1,5-L$-arabinan. ${ }^{16-18)}$}

\section{Purification and properties of an exo-arabinanase.}

The P. chrysogenum 31B strain has been found to produce at least six different enzymes which degrade arabinose-containing polymers. These include an exo-1,5$\alpha$-L-arabinanase (no EC number), ${ }^{16)}$ two $\alpha$-L-arabinofuranosidase (EC 3.2.1.55), ${ }^{19)}$ an arabinoxylan arabinofura- 
nohydrolase (EC 3.2.1.55), and two endo-1,5- $\alpha-\mathrm{L}-$ arabinanses (EC 3.2.1.99). ${ }^{20)}$ To the best of my knowledge, no article dealing with an exo-arabinanase has been published. Characteristics of an exo-arabinanase, termed Abnx, produced by this strain are described here.

Abnx was purified from a culture filtrate of $P$. chrysogenum $31 \mathrm{~B}$ and had an apparent molecular mass of 47 $\mathrm{kDa}$. For determination of the mode of the enzyme action towards linear arabinan, $0.08 \mathrm{mU}$ of Abnx was incubated with $200 \mu \mathrm{L}$ of $0.2 \%$ reduced debranched arabinan in 20 $\mathrm{mM}$ acetate buffer $\left(\mathrm{pH} \mathrm{5.0)}\right.$ ) at $37^{\circ} \mathrm{C}$ and the products from different times of reaction were analyzed by HPAEC. Only arabinobiose was detected from the early stage of enzyme reaction. Moreover, no arabinofuranosyl arabitol was formed in the course of degradation of reduced debranched arabinan (Fig. 3). These results indicated that Abnx cleaved $\alpha-1,5$-L-linked arabinofuranose residues at their non-reducing terminus in an exo manner.

Enzyme activity towards arabinose-containing substrates was examined. The enzyme significantly released arabinobiose from debranched arabinan. Minor activity was detected on soybean arabinogalactan and branched Larabinan. The enzyme did not cleave the following substrates: $p$-nitrophenyl $\alpha$-L-arabinofuranoside, $p$-nitrophenyl $\alpha$-L-arabinopyranoside, larch wood arabinogalactan, or $\alpha-1,5$-L-arabinofuranobiose. The enzyme activity was 10 times higher on debranched arabinan than on branched Larabinan. Considering the structure of the two substrates, these results indicated that activity of Abnx was interfered by arabinose side chains attached to arabinan backbones.

\section{Molecular cloning and overexpression of an exo- arabinanase gene.}

For determination of the nucleotide sequence of the abnx gene, which encodes Abnx, cassette-ligation mediated PCR was performed using primers constructed on the basis of the N-terminal and partial internal amino acid sequences of Abnx. A 1695-bp sequence from the putative ATG start codon of the abnx gene was determined (GenBank accession number AB096108). To clone the fulllength abnx cDNA, two primers were synthesized based on the sequencing data of genomic DNA. The two primers were used for PCR amplification using the cDNA that

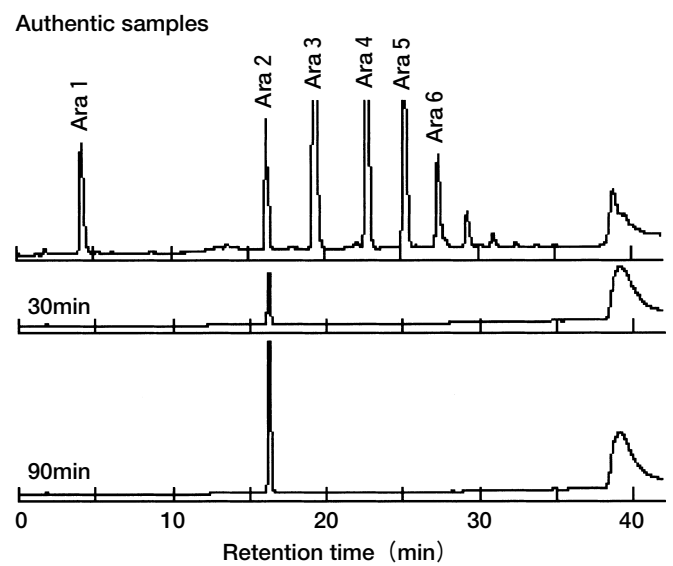

Fig. 3. Analysis of the enzymatic products of reduced debranched arabinan with Abnx.

Authentic samples: Ara1 to Ara6 represent arabinose to arabinohexaose, respectively. was reverse transcribed from total RNA of $P$. chrysogenum $31 \mathrm{~B}$ as the template. The coding sequence of the abnx gene contained 1134 bp which encodes a protein of 378 amino acids with a calculated molecular mass of 41,636 Da and a calculated isoelectric point of 5.11.

Arabinan-degrading enzymes have been mainly grouped into four glycosyl hydrolase $(\mathrm{GH})$ families based on their amino acid sequence (GH 43, GH 51, GH 54 and GH 62) (http://afmb.cnrs-mrs.fr/CAZY/index.html). Four A. niger enzymes that are examples of each of these respective families are endo-1,5- $\alpha$-L-arabinanase $(a b n A),{ }^{21)} \quad \alpha-\mathrm{L}-$ arabinofuranosidase $(a b f A),{ }^{22)} \quad \alpha$-L-arabinofuranosidase $(a b f B)^{23)}$ and 1,4- $\beta$-D-arabinoxylan arabinofuranohydrolase $(\operatorname{axh} A) .{ }^{24)}$ However, the deduced amino acid sequence of Abnx has no similarity to the deduced sequences of enzymes belonging to these $\mathrm{GH}$ families. Although the identities of these amino acid sequences were low, comparisons of primary structures of proteins are generally not a reliable way to detect structural similarities. Therefore, a HCA was performed to more precisely classify Abnx. HCA allows detection of conserved secondary structure elements in proteins which show low sequence identity. ${ }^{25,26)}$ Abnx was compared with the mentioned four $A$. niger arabinan-degrading enzymes. The secondary structures were also predicted by PHDsec on the Internet (http://cubic.bioc.columbia.edu/pp/). No structural similarity was found between Abnx and the four A. niger enzymes (data not shown), demonstrating that Abnx is distinct from known arabinan-degrading enzymes in terms of protein structure. Recently, Abnx has been grouped into GH 93 with six hypothetical proteins (two from A. nidulans, two from Neurospora crassa, one from Bacteroides thetaiotaomicron and one from Magnaporthe grisea) and a Streptomyces coelicolor putative bifunctional protein.

In order to obtain the mature Abnx, the region amplified by PCR was ligated to the pMAL-c2X vector (New England BioLabs), forming a new plasmid termed pMALAX. Because the PCR product was inserted into a pMALc2X downstream from the malE gene, which encodes maltose binding protein (MBP), the recombinant Abnx expressed from pMAL-AX was expected to be a MBPfusion Abnx. The recombinant protein in the cell-free extract of E. coli DH5 $\alpha$ transformed with the plasmid was purified using an Amylose Resin column (New England BioLabs).

\section{Characteristics of the recombinant Abnx.}

The kinetic parameters of the recombinant Abnx towards arabino-oligosaccharides with different DPs (DP 2

Table 3. Kinetic parameters of the recombinant Abnx towards arabino-oligosaccharides with different DPs.

\begin{tabular}{ccc}
\hline Substrate & $K_{\mathrm{m}}(\mathrm{mM})$ & $k$ cat $/ K_{\mathrm{m}}\left(\mathrm{s}^{-1} \cdot \mathrm{mM}^{-1}\right)$ \\
\hline DP3 & 1.01 & 3.01 \\
DP4 & 0.85 & 11.53 \\
DP5 & 0.63 & 17.80 \\
DP6 & 0.33 & 39.22 \\
DP7 & 0.36 & 32.62 \\
\hline
\end{tabular}

In a typical assay, $0.168 \mu \mathrm{g}$ of the enzyme was incubated with various concentrations of arabino-oligosaccharide as the substrate. The data were analyzed by Lineweaver-Burk plots using a leastsquares linear regression. 
to DP 7) were examined at $\mathrm{pH} 5.0$ and $37^{\circ} \mathrm{C}$. Table 3 shows that $k_{\mathrm{cat}} / K_{\mathrm{m}}$ increased with increasing of DP, reaching the highest value at DP 6 .

In order to study the action pattern of the recombinant Abnx, product formation at different reaction times was monitored with HPAEC using $\alpha-1,5$-L-arabinoheptaose as the substrate. Based on the mode of action of Abnx, the substrate $\alpha-1,5-\mathrm{L}$-arabinoheptaose would be expected to yield arabinopentaose, arabinotriose, arabinobiose and arabinose. During the early stage of the enzyme reaction, arabinobiose and arabinopentaose, but not arabinotriose, were formed. During later stages of the reaction, arabinobiose and arabinotriose accumulated and a small amount of arabinose was detected (Fig. 4). Generally enzymes degrade substrates in either multi-chain or single-chain attack mode. The data obtained here suggest that Abnx acts in a multi-chain attack mode and that arabinotriose is more resistant to the enzyme than larger oligomers as demonstrated in Table 3.

Acceptor specificity of Abnx was examined by incubat-

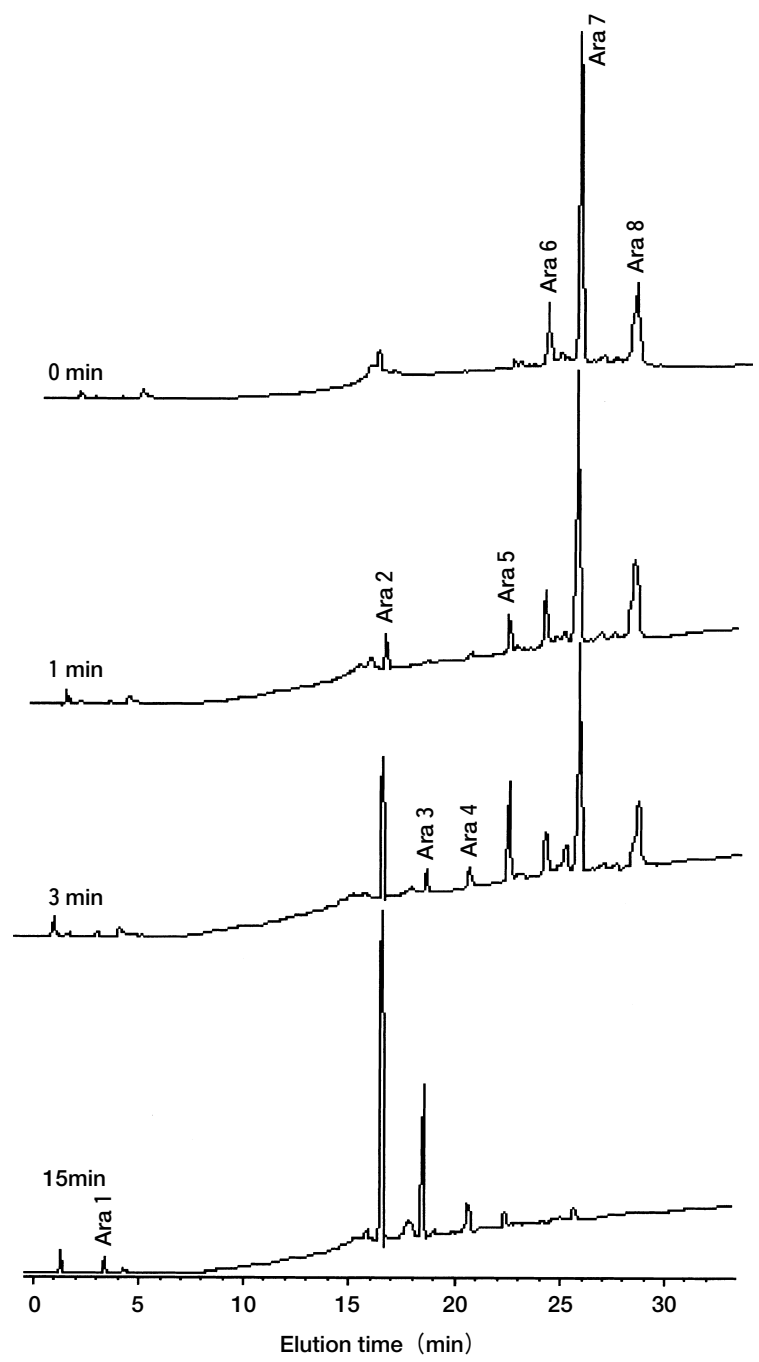

Fig. 4. Analysis of the enzymatic products of $\alpha-1,5$-L-arabinoheptaose with the recombinant MBP-fusion Abnx.

A reaction mixture containing $7 \mu \mathrm{g}$ of the enzyme and $100 \mu \mathrm{L}$ of $5 \mathrm{mM}$ arabinoheptaose in $20 \mathrm{mM}$ acetate buffer (pH 5.0) was incubated at $37^{\circ} \mathrm{C}$ for the times shown. Aliquots were taken at intervals and inactivated by boiling for $5 \mathrm{~min}$, followed by analysis of the reaction products with HPAEC. Ara1 to Ara8 represent arabinose to arabinooctaose, respectively. ing acceptors including aliphatic alcohols, sugars and sugar alcohols, with the recombinant Abnx in the presence of debranched arabinan. The transglycosylation activities of the enzyme towards various compounds are summarized in Table 4. Abnx was able to synthesize transfer products in the presence of most alcohols tested. Comparison of the transglycosylation activities towards $\mathrm{C} 4$ alcohols can help to determine specificity of the enzyme. Monohydroxybutanes such as 1-butanol and 2butanol were not good acceptors. Abnx efficiently transferred arabinobiose to 1,2-butanediol and 1,3-butanediol but not to 2,3-butanediol. These results suggest that the enzyme preferred the primary hydroxyl group in polyhydroxybutanes as acceptors. When sugars were used as acceptors, two or three transfer products were detected. The transfer activity of Abnx was higher towards sugar alcohols than towards sugars. Among the tested compounds, glycerol was the best acceptor for transglycosylation with Abnx.

Large-scale synthesis of transfer products was done to identify the structure of the transfer products of glycerol. The reaction was carried out at $\mathrm{pH} 4$ and $40^{\circ} \mathrm{C}$ in the presence of $20 \%$ glycerol and $1 \%$ debranched arabinan. Two transfer products were synthesized at a ratio of 11:1 (Table 4). In this study, only the major product, termed GA, was isolated by a Sep-Pak Vac $20 \mathrm{cc}\left(\mathrm{NH}_{2}\right.$ cartrides; Waters) and a CarboPac PA-1 column. FAB-MS spectra of GA gave a significant molecular ion peak at $\mathrm{m} / \mathrm{z} 357$ $[\mathrm{M}+\mathrm{H}]^{+}$. Adding NaI solution, an adduct ion peak $\mathrm{m} / \mathrm{z}$ $379[\mathrm{M}+\mathrm{Na}]^{+}$was observed. This data was consistent with a molecular formula of $\mathrm{C}_{13} \mathrm{H}_{24} \mathrm{O}_{11}$ (molar mass: 356) and the structure of arabinobiosyl glycerol. The structure of GA was confirmed by ${ }^{1} \mathrm{H}$ - and ${ }^{13} \mathrm{C}$-NMR spectroscopy.

Table 4. Transglycosylation activity of Abnx on various compounds.

\begin{tabular}{|c|c|c|c|}
\hline \multirow[b]{2}{*}{ Acceptor } & \multicolumn{3}{|c|}{ Area of product } \\
\hline & Arabinobiose & $\begin{array}{c}\text { Major transfer } \\
\text { product }\end{array}$ & $\begin{array}{c}\text { 2nd-major } \\
\text { transfer product }\end{array}$ \\
\hline None & 214 & - & - \\
\hline Methanol & 125 & 25 & - \\
\hline Ethanol & 113 & 6 & - \\
\hline 1-Propanol & 18 & 3 & - \\
\hline 1,2-Propanediol & 96 & 56 & 5 \\
\hline 1,3-Propanediol & 64 & 83 & - \\
\hline 1-Butanol & 43 & 6 & - \\
\hline 2-Butanol & 53 & - & - \\
\hline 1,2-Butanediol & 47 & 44 & 6 \\
\hline 1,3-Butanediol & 77 & 60 & 3 \\
\hline 1,4-Butanediol & 72 & 18 & - \\
\hline 2,3-Butanediol & 119 & 10 & - \\
\hline 1-Pentanol & 85 & 4 & - \\
\hline Glycerol & 70 & 182 & 17 \\
\hline Sorbitol & 160 & 104 & - \\
\hline Xylitol & 139 & 141 & 4 \\
\hline Arabinose & 126 & 33 & 30 \\
\hline Fructose & 163 & 57 & 20 \\
\hline Galactose & 141 & 26 & 24 \\
\hline Glucose & 118 & 49 & 25 \\
\hline Rhamnose & 141 & 29 & - \\
\hline Xylose & 105 & 31 & 6 \\
\hline
\end{tabular}

Areas of the products released into the mixture were determined by HPAEC. The area ratios given are not true product ratios although PAD responses are often approximately equimolar. 
All signals were assigned by ${ }^{1} \mathrm{H}-$ and ${ }^{13} \mathrm{C}-\mathrm{NMR}$, DEPT (distortionless enhancement by polarization transfer), and two dimensional NMR methods. The ${ }^{1} \mathrm{H}-$ and ${ }^{13} \mathrm{C}-\mathrm{NMR}$ spectral data of GA are shown in Table 5. Four sets of carbon signals from hydroxymethyl groups were detected at $\delta c 63.1,64.3$ (64.3), 68.2 and 70.2 (70.25). These signals were consistent with the provisional structure, which would give signals from $\mathrm{C}-5$ and $\mathrm{C}-5^{\prime \prime}$ of the two arabinosyl residues, and also from the two glyceryl terminal carbons C-1' and C-3' (made non-equivalent by arabinosylation) (Fig. 5). In addition, arabinosylation would make the $\mathrm{C}^{-2} 2^{\prime}$ of the glyceryl residue asymmetric, leading to formation of two diastereomeric arabinobiosyl glycerol molecules, and two signals for both $\mathrm{C}-1^{\prime}$ and $\mathrm{C}-3^{\prime}$ (data in parentheses above for one diastereomer). The signal at $\delta_{\mathrm{C}} 68.2$ was correlated to the anomeric proton $\mathrm{C}-1$ " at $\delta_{\mathrm{H}}$ 4.93 by a COLOC (correlation spectroscopy via long-

Table 5. ${ }^{1} \mathrm{H}$ - and ${ }^{13} \mathrm{C}-\mathrm{NMR}$ spectral data for the transfer product (GA).

\begin{tabular}{|c|c|c|c|}
\hline & Position & $\begin{array}{c}{ }^{13} \mathrm{C}-\mathrm{NMR} \\
\delta \mathrm{C}\end{array}$ & $\begin{array}{c}{ }^{1} \mathrm{H}-\mathrm{NMR} \\
\delta \mathrm{H}(\text { integral, mult., } J \mathrm{~Hz})\end{array}$ \\
\hline \multirow[t]{6}{*}{ Glycerol } & $1^{\prime}$ & $70.20^{\mathrm{a}}$ & $\begin{array}{l}3.43(1 \mathrm{H}, \mathrm{m}) \\
3.77(1 \mathrm{H}, \mathrm{m})\end{array}$ \\
\hline & & $70.25^{\mathrm{a}}$ & $\begin{array}{l}3.50(1 \mathrm{H}, \mathrm{dd}, J=4.3,10.4 \mathrm{~Hz}) \\
3.69(1 \mathrm{H}, \mathrm{dd}, J=6.4,10.4 \mathrm{~Hz})\end{array}$ \\
\hline & $2^{\prime}$ & $72.11^{\mathrm{b}}$ & $3.78(1 \mathrm{H}, \mathrm{m})$ \\
\hline & & $72.20^{\mathrm{b}}$ & $3.76(1 \mathrm{H}, \mathrm{m})$ \\
\hline & $3^{\prime}$ & $64.27^{\mathrm{c}}$ & $\begin{array}{l}3.53(1 \mathrm{H}, \mathrm{dd}, J=7.0,11.3 \mathrm{~Hz}) \\
3.58(1 \mathrm{H}, \mathrm{dd}, J=1.8,11.3 \mathrm{~Hz})\end{array}$ \\
\hline & & $64.32^{\mathrm{c}}$ & $\begin{array}{l}3.52(1 \mathrm{H}, \mathrm{dd}, J=7.0,11.3 \mathrm{~Hz}) \\
3.57(1 \mathrm{H}, \mathrm{dd}, J=1.8,11.3 \mathrm{~Hz})\end{array}$ \\
\hline \multirow[t]{6}{*}{$\begin{array}{l}\text { Arabinose } \\
\text { (5-linked) }\end{array}$} & 1 & $\begin{array}{l}109.80^{\mathrm{d}} \\
109.96^{\mathrm{d}}\end{array}$ & $\begin{array}{l}4.88(1 \mathrm{H}, \mathrm{d}, J=1.5 \mathrm{~Hz}) \\
4.88(1 \mathrm{H}, \mathrm{d}, J=1.5 \mathrm{~Hz})\end{array}$ \\
\hline & 2 & 83.23 & $3.98(1 \mathrm{H}, \mathrm{dd}, J=1.5,3.1 \mathrm{~Hz})$ \\
\hline & 3 & 79.18 & $3.90(1 \mathrm{H}, \mathrm{dd}, J=3.1,5.8 \mathrm{~Hz})$ \\
\hline & 4 & $84.22^{\mathrm{e}}$ & $4.05(1 \mathrm{H}, \mathrm{m})$ \\
\hline & & $84.26^{\mathrm{e}}$ & $4.05(1 \mathrm{H}, \mathrm{m})$ \\
\hline & 5 & 68.21 & $\begin{array}{l}3.65(1 \mathrm{H}, \mathrm{dd}, J=4.0,11.0 \mathrm{~Hz}) \\
3.85(1 \mathrm{H}, \mathrm{dd}, J=5.2,11.0 \mathrm{~Hz})\end{array}$ \\
\hline \multirow{6}{*}{$\begin{array}{l}\text { Arabinose } \\
\text { (non-reducing } \\
\text { end) }\end{array}$} & $1^{\prime \prime}$ & 109.63 & $4.93(1 \mathrm{H}, \mathrm{d}, J=1.5 \mathrm{~Hz})$ \\
\hline & $2^{\prime \prime}$ & 83.14 & $3.99(1 \mathrm{H}, \mathrm{dd}, J=1.5,3.1 \mathrm{~Hz})$ \\
\hline & $3^{\prime \prime}$ & 78.71 & $3.83(1 \mathrm{H}, \mathrm{dd}, J=3.1,5.8 \mathrm{~Hz})$ \\
\hline & $4^{\prime \prime}$ & 85.86 & $3.97(1 \mathrm{H}, \mathrm{dd}, J=3.4,5.8 \mathrm{~Hz})$ \\
\hline & $5^{\prime \prime}$ & 63.05 & $3.63(1 \mathrm{H}, \mathrm{dd}, J=5.5,11.9 \mathrm{~Hz})$ \\
\hline & & & $3.74(1 \mathrm{H}, \mathrm{dd}, J=3.4,11.9 \mathrm{~Hz})$ \\
\hline
\end{tabular}

The spectra were measured at $500 \mathrm{MHz}$ for ${ }^{1} \mathrm{H}$ and at $125 \mathrm{MHz}$ for ${ }^{13} \mathrm{C}$. ${ }^{\text {ae }}$ Superscripted data are for pairs of diastereotopic carbons (see text).

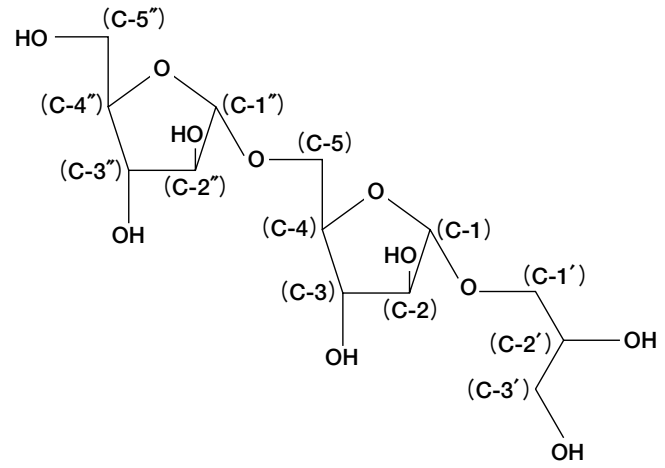

Fig. 5. The postulated structure of GA.

The numbers in the parentheses show the carbon assignments used in the text. range coupling) spectrum. Likewise the signal at $\delta \mathrm{C} 70.20$ (70.25) was correlated to other anomeric proton $\mathrm{C}-1$ at $\delta_{\mathrm{H}}$ 4.88 in the spectrum. These data indicated that the arabinobiosyl residue was linked to a primary hydroxyl of glycerol. Three peaks appeared in the region for anomeric carbons of the arabinose residues: the signal at $\delta \mathrm{c} 109.6$ was assigned to the non-reducing end arabinose and the other two peaks (at $\delta \mathrm{C} 109.8$ and 110.0) were assigned to the 5-linked arabinose residues. The integrated areas of the latter two ${ }^{13} \mathrm{C}-\mathrm{NMR}$ peaks were similar, indicating that the two diastereomers were formed in almost equal amounts. The two glycosidic linkages in GA were determined to be the $\alpha$-configuration on the basis of the coupling constants $(J=1.5 \mathrm{~Hz})$ of the anomeric protons. Accordingly, the structure of GA was elucidated to be $O-\alpha$ L-arabinosyl- ( $1 \rightarrow 5$ )-O- $\alpha$-L-arabinosyl- ( $1 \rightarrow 1$ ) -glycerol, demonstrating that the anomeric configuration of arabinose is conserved in the hydrolysis of linear arabinan by Abnx.

In conclusion, Abnx secreted by P. chrysogenum 31B is an unusual arabinan-degrading enzyme with respect to both its mode of action and protein structure. The enzyme catalyzes the hydrolysis of linear arabinan without inverting the anomeric configuration.

\section{REFERENCES}

1 ) Y. Matsuura and C. Hatanaka: Isolation and characterization of a xylose-rich pectic polysaccharide from Japanese radish. Agric. Biol. Chem., 52, 3215-3216 (1988).

2 ) A. Kikuchi, Y. Edashige, T. Ishii and S. Satoh: A xylogalacturonan whose level is dependent on the size of cell clusters is present in the pectin from cultured carrot cells. Planta, 200, 369-372 (1996).

3 ) G. Beldman, L.A.M. van den Broek, H.A. Schols, M.J.F. Searle-van Leeuwen, K.M.J. van Laere and A.G.J. Voragen: An exogalacturonase from Aspergillus aculeatus able to degrade xylogalacturonan. Biotechnol. Lett., 18, 707-712 (1996).

4 ) H.A. Schols, E.J. Bakx, D. Schipper and A.G.J. Voragen: A xylogalacturonan subunit present in the modified hairy regions of apple pectin. Carbohydr. Res., 279, 265-279 (1995).

5 ) A. Le Goff, C.M.G.C. Renard, E. Bonnin and J.F. Thibault: Extraction, purification and chemical characterisation of xylogalacturonans from pea hulls. Carbohydr. Polym., 45, 325334 (2001).

6 ) J.R. Whitaker: Pectic substances, pectic enzymes and haze formation in fruit juices. Enzyme Microb. Technol., 6, 341-349 (1984).

7 ) T. Sakamoto, E. Bonnin, B. Quemener and J.F. Thibault: Purification and characterisation of two exo-polygalacturonases from Aspergillus niger able to degrade xylogalacturonan and acetylated homogalacturonan. Biochim Biophys Acta, 1572, 1018 (2002).

8 ) P.J. Mill: The pectic enzymes of Aspergillus niger, a mercuryactivated exopolygalacturonase. Biochem. J., 99, 557-561 (1966).

9 ) T. Hara, J.Y. Lim, Y. Fujio and S. Ueda: Purification and some properties of exo-polygalacturonase from Aspergillus niger cultured in the medium containing sastuma mandarin peel. Nippon Shokuhin Kogyo Gakkaishi, 31, 581-586 (1984).

10) H.C.M. Kester, M.A. Kusters-van Someren, Y. Müller and J. Visser: Primary structure and characterization of an exopolygalacturonase from Aspergillus tubingensis. Eur. J. Biochem., 240, 738-746 (1996).

11) R. Körner, G. Limberg, T.M.I.E. Christensen, J.D. Mikkelsen and P. Roepstorff: Sequencing of partially methyl-esterified oligogalacturonates by tandem mass spectrometry and its use to determine pectinase specificities. Anal. Chem., 71, 1421- 
1427 (1999).

12) G.E. Hofmeister, Z. Zhou and J.A. Leary: Linkage position determination in lithium-cationized disaccharides: tandem massspectrometry and semiempirical calculations. J. Am. Chem. Soc., 113, 5964-5970 (1991).

13) D. Garozzo, M. Giuffrida, G. Impallomeni, A. Ballistreri and G. Montaudo: Determination of linkage position and identification of the reducing end in linear oligosaccharides by negativeion fast atom bombardment mass-spectrometry. Anal. Chem., 62, 279-286 (1990).

14) H.C.M. Kester, J.A.E. Benen and J. Visser: The exopolygalacturonase from Aspergillus tubingensis is also active on xylogalacturonan. Biotechnol. Appl. Biochem., 30, 53-57 (1999).

15) C.J.B. van der Vlugt-Bergmans, P.J.A. Meeuwsen, A.G.J. Voragen and A.J.J. van Ooyen: Endo-xylogalacturonan hydrolase, a novel pectinolytic enzyme. Appl. Environ. Microbiol., 66, 3641 (2000).

16) T. Sakamoto and J.F. Thibault: Exo-arabinanase of Penicillium chrysogenum able to release arabinobiose from $\alpha-1,5-\mathrm{L}-$ arabinan. Appl. Environ. Microbiol., 67, 3319-3321 (2001).

17) T. Sakamoto, H. Ihara, A. Shibano, N. Kasai, H. Inui and H. Kawasaki: Molecular characterization of a Penicillium chrysogenum exo-1,5- $\alpha$-L-arabinanase that is structurally distinct from other arabinan-degrading enzymes. FEBS Lett., 560, 199204 (2004).

18) T. Sakamoto, T. Fujita and H. Kawasaki: Transglycosylation catalyzed by a Penicillium chrysogenum exo-1,5- $\alpha$-L-arabinanase. Biochim. Biophys. Acta, 1674, 85-90 (2004).

19) T. Sakamoto and H. Kawasaki: Purification and properties of two type-B $\alpha$-L-arabinofuranosidases produced by Penicillium chrysogenum. Biochim. Biophys. Acta, 1621, 204-210 (2003).

20) T. Sakamoto, H. Ihara, S. Kozaki and H. Kawasaki: A coldadapted endo-arabinanase from Penicillium chrysogenum. Biochim. Biophys. Acta, 1624, 70-75 (2003).

21) M.J.A. Flipphi, H. Panneman, P. van der Veen, J. Visser and L. H. de Graaff: Molecular cloning, expression and structure of the endo-1,5- $\alpha$-L-arabinase gene of Aspergillus niger. Appl. Microbiol. Biotechnol., 40, 318-326 (1993).

22) M.J.A. Flipphi, J. Visser, P. van der Veen and L. H. de Graaff: Arabinase gene expression in Aspergillus niger indications for coordinated regulation. Microbiology, 140, 26732682 (1994)

23) M.J.A. Flipphi, M. van Heuvel, P. van der Veen, J. Visser and L. H. de Graaff: Cloning and characterization of the $a b f \mathrm{~B}$ gene coding for the major $\alpha$-L-arabinofuranosidase (ABF B) of Aspergillus niger. Curr. Genet., 24, 525-532 (1993).

24) M.M. Gielkens, J. Visser and L. H. de Graaff: Arabinoxylan degradation by fungi: characterization of the arabinoxylanarabinofuranohydrolase encoding genes from Aspergillus niger and Aspergillus tubingensis. Curr. Genet., 31, 22-29 (1997).

25) L. Lemesle-Varloot, B. Henrissat, C. Gaboriaud, V. Bissery, A. Morgat and J.P. Mornon: Hydrophobic cluster analysis: procedures to derive structural and functional information from 2-D-representation of protein sequences. Biochimie, 72, 555574 (1990).

26) I. Callebaut, G. Labesse, P. Durand, A. Poupon, L. Canard, J. Chomilier, B. Henrissat and J.P. Mornon: Deciphering protein sequence information through hydrophobic cluster analysis (HCA): current status and perspectives. Cell Mol. Life Sci., 53, 621-645 (1997).

\section{カビの生産する新規機能を有する エキソ型酵素に関する研究}

阪本龍司 ${ }^{1}$

\section{${ }^{1}$ 大阪府立大学大学院生命環境科学研究科}

(599-8531 堺市学園町 1-1)

(1) Aspergillus niger 由来のエキソポリガラクチュロ ナーゼ (Exo-PG) の機能解析：ペクチン中のガラクチュロ
ン酸残基は部分的にメタノールや酢酸，キシロースで修 飾されている. 本研究ではA. nigerより 2 種の Exo-PGを 単離し, 種々のタイプのペクチン質に対する特異性を検 討した。 その結果, 両酵素ともにキシロガラクチュロナ ンおよびアセチル化ホモガラクチュロナンを末端から切 断し，キシロガラクチュロン酸およびアセチル化ガラク チュロン酸を生成することを ESI-ITMS 分析等により明ら かにした。すなわち, Exo-PG はホモガラクチュロナンに 結合するキシロースや酢酸によって反応が妨害されない ことが判明し，ペクチン中の修飾基分布の解析に有効で あることが示唆された. (2) Penicillium chrysogenum 由来 のエキソアラビナナーゼの機能解析：直鎖状還元型アラ ビナンを基質として, 本酵素の反応産物を HPAEC 分析し た結果, 本酵素は非還元末端よりビオース単位で切断す ることが明らかとなった。 DP 7 を基質として, 酵素反応 産物の経時変化を分析することにより，本酵素は“multichain attack mode”で基質に作用することを明らかにした。 種々のアルコール，糖の存在下で直鎖型アラビナンに本 酵素を作用させると，アラビノビオース転移能を示した。 グリセリンを受容体とした場合の主要転移産物を単離し, その構造を NMR 等により $O$ - $\alpha$-L-arabinosyl- $(1 \rightarrow 5)-O-\alpha-\mathrm{L}-$ arabinosyl- $(1 \rightarrow 1)$-glycerol と決定した。このことから本酵 素はアノマー保持型酵素であることが証明された。さら に本酵素遺伝子の塩基配列を決定し，アミノ酸配列相同 性検索と疎水性クラスター解析の結果から, 本酵素は既 報のアラビナン分解酵素とは異なるタンパク構造を有し ていることが判明し，7種の機能未知タンパク質とともに 新たに $\mathrm{GH}$ ファミリー93 が形成された.

\section{〔質 問〕}

信州大 北畑

Fig. 2 において，エキソポリガラクチュロナーゼにより 生成するガラクチュロン酸とキシロガラクチュロン酸の 生成比率は基質のキシロガラクチュロナンの構造と矛盾 しないですか.

\section{【答〕}

基質に用いたキシロガラクチュロナン中の全 GalA 残基 のうち $28 \%$ がフリー，53\%がキシロース，19\%がキシロ ビオースで修飾されています。この数值と反応液組成を 考慮すると, 酵素反応に使用した基質中には GalA, GalAXyl, GalA-Xyl2 の濃度はそれぞれ96,319, $163 \mu \mathrm{g} / \mathrm{mL}$ と計算できます。Exo-PGにより48時間後に遊離された GalA と GalA-Xyl の濃度はそれぞれ 40.1 と $60.2 \mu \mathrm{g} / \mathrm{mL} て ゙$ あり, 基質中の $42 \%$ の GalA と 19\%の GalA-Xyl が遊離さ れたことになります。基質全体としては $22 \%$ の $\alpha-1,4-$ GalA 結合が切断された計算となります。また, Fig. 2 に おいて反応前半では GalA の生成比率が高いことから, 基 質中のキシロースによる修飾は均一ではなく，部分的に 集中している領域が存在しているのではないかと考えて 
おります。

〔質 問〕

石川県大 谷口

Abnx をアラビノースヘプタオースに作用させたとき， アラビノースは生成しないのでしょうか? また，アラビ ノトリオースに作用させたとき，アラビノビオースは多 量に生成するのでしょうか?

〔答〕

DP 3-7 のアラビノオリゴ糖に対する特異性を調べた結
果, 本酵素は重合度に比例して活性は高くなり, DP 6 で 最大活性を示し, DP 3 に対しては微弱であります (Table 3). また, 本酵素にはアラビノビオース分解活性はあり ません，したがって，アラビノへプタオースを基質とし た場合には主要反応産物としてアラビノビオースとアラ ビノトリオースを蓄積します (Fig. 4). しかし, 過剩の酵 素反応を行いますと, アラビノトリオースはアラビノー スとアラビノビオースに分解します。 